\title{
Solitary Dorsal Intramedullary Schwanomma - A Rare Lesion
}

\section{Schwanomma intramedular dorsal solitário - Uma lesão rara}

\author{
Laxmikant Bhople ${ }^{1}$ Hrushikesh Kharosekar ${ }^{10}$ Nimesh Jain ${ }^{1}$ Vernon Velho ${ }^{1}$ \\ ${ }^{1}$ Department of Neurosurgery, Sir J J group of Hospitals and Grant \\ Medical College, Mumbai, Maharashtra, India \\ Arq Bras Neurocir 2022;41(1):e90-e93.

\begin{abstract}
Address for correspondence Hrushikesh Kharosekar, MCh, Department of Neurosurgery, 4th floor, Grant Medical College and Sir J] Group of Hospitals, Byculla E, Mumbai, Maharashtra, 400008, India (e-mail: hkharosekar@gmail.com).
\end{abstract}

\begin{abstract}
Intramedullary schwanommas are rare, and most cases are reported in cervical region. Less than 20 dorsal intramedullary schwanommas have been reported till date in

Keywords

- dorsal

- intramedullary

- schwanomma

Resumo
Palavras-chave
- dorsal
- intramedular
- schwanomma literature. This is due to their cell of origin, the Schwann cell, which is not normally found within the parenchyma of the brain and spinal cord; therefore it is not surprising that these lesions are rare. We report a rare solitary dorsal intramedullary schwanomma in a young adult patient who presented with paraplegia.

Schwanommas intramedulares são raros, e a maioria dos casos são relatados na região cervical. Menos de 20 schwanommas intramedulares dorsais foram relatados até o momento na literatura. Isso se deve à sua célula de origem, a célula de Schwann, que normalmente não é encontrada dentro do parênquima do cérebro e da medula espinhal; portanto, não é surpreendente que essas lesões são raras. Nós relatamos um raro schwanomma intramedular dorsal solitário em um paciente adulto jovem que apresentou paraplegia.
\end{abstract}

\section{Introduction}

Schwanommas account for $30 \%$ of primary intraspinal tumors. Intra-spinal schwanommas are usually located in the intradural extramedullary (IDEM) space, and are rarely intramedullary. Intramedullary schwanommas (ISs) only account for $0.3 \%$ of intraspinal tumors, and for $1.1 \%$ of intraspinal schwanommas. ${ }^{1}$ Most ISs are found in the region of the cervical cord, and less than 20 cases of been reported in dorsal region to date. The cell of origin of the schwanomma is the Schwann cell, which is not normally found within the parenchyma of the brain and spinal cord; therefore, it is not surprising that these lesions are rare. Several theories have been postulated to explain the origin of these tumors, but none has gained universal acceptance. We report a rare case of solitary dorsal IS in a young patient who presented with paraplegia., ${ }^{2,3}$

\section{Case}

A 20-year-old female patient presented with back pain that had been felt for 1 year, with gradually progressive weakness in both lower limbs in the previous 2 months. Upon neurological examination, she had paraparesis in both lower limbs with a power of $3 / 5$ on the myelomeningocele (MMC) scale. She also had bowel and bladder incontinence. Her sensory examination revelaed loss of sensation below the level of D5. received

September 18, 2020

accepted

February 22, 2021

published online

November 1, 2021
DOI https://doi.org/ 10.1055/s-0041-1730333. ISSN 0103-5355.

\footnotetext{
(c) 2021. Sociedade Brasileira de Neurocirurgia. All rights reserved. This is an open access article published by Thieme under the terms of the Creative Commons Attribution-NonDerivative-NonCommercial-License, permitting copying and reproduction so long as the original work is given appropriate credit. Contents may not be used for commercial purposes, or adapted, remixed, transformed or built upon. (https://creativecommons.org/ licenses/by-nc-nd/4.0/) Thieme Revinter Publicações Ltda., Rua do Matoso 170, Rio de Janeiro, RJ, CEP 20270-135, Brazil
} 


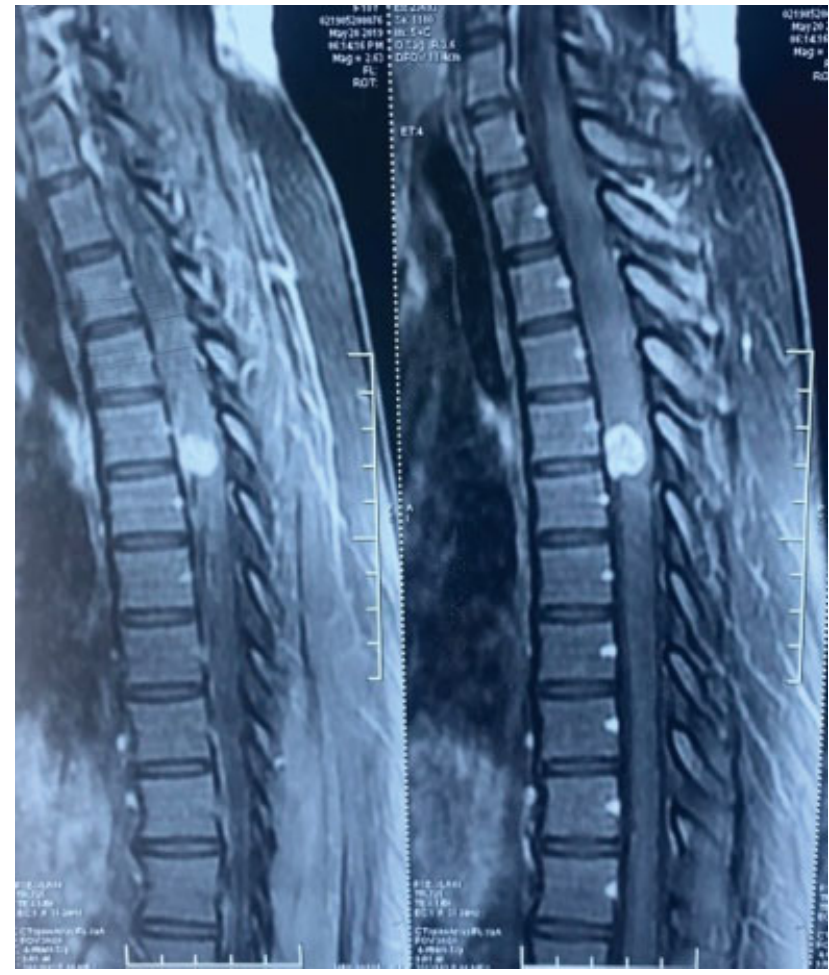

Fig. 1 Preoperative magnetic resonance imaging (MRI) scan of the dorsal spine with contrast showing the intramedullary contrast-enhancing lesion.

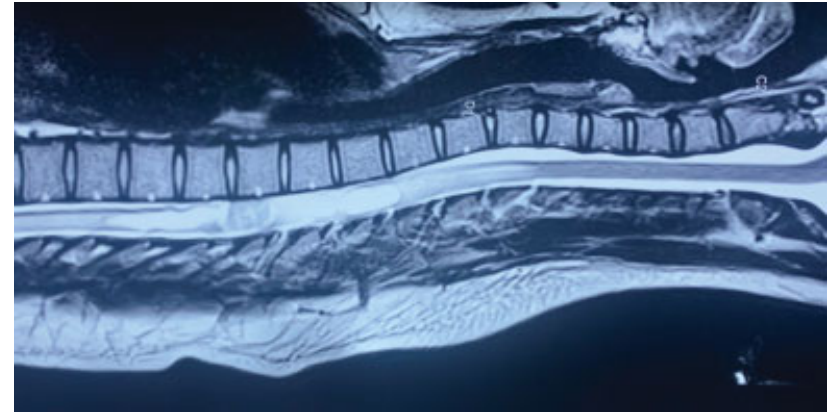

Fig. 3 Preoperative MRI of the dorsal spine: T2-weighted images showing the intramedullary lesion and cord expansion with syrinx formation.

She was submitted to a magnetic resonance imaging (MRI) scan of the dorsal spine with contrast, which revealed a welldefined heterogeneously enhancing intramedullary lesion with expansion of cord and perilesional edema at the level of D5 to D6 (-Figs. 1-23). The patient operated with the differential diagnoses of intramedullary tuberculoma or glioma in mind. She underwent dorsal (D4 to D6) laminotomy with complete excision of the lesion. Intraoperatively, a greyish-white, well-defined, firm, non-suckable intramedullary lesion was found (- Figs. 4-567). Postoperatively, there was minimal improvement in power in both lower limbs. The patient was discharged with an indication for physiotherapy and regular follow-up.

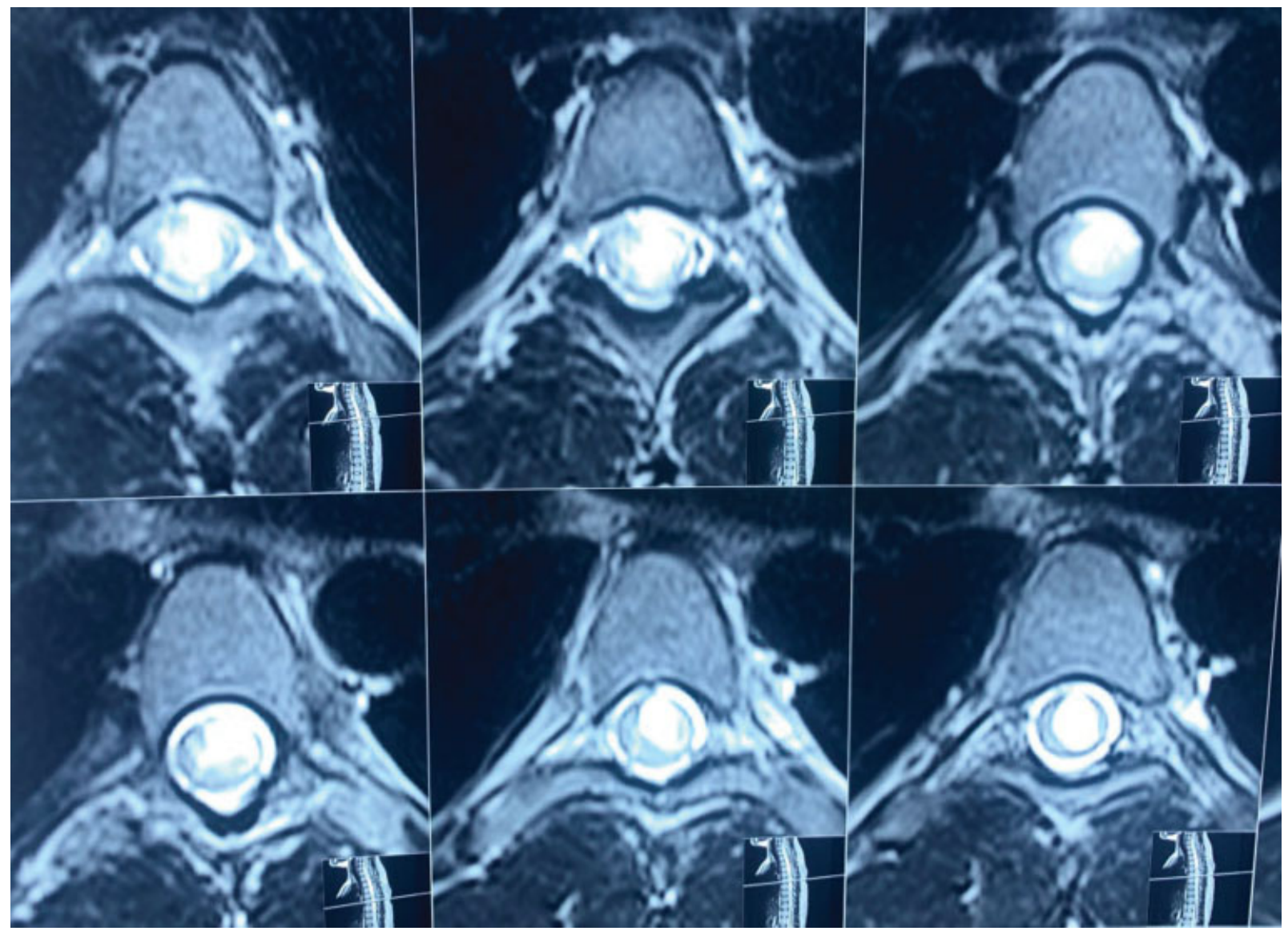

Fig. 2 Preoperative magnetic resonance imaging (MRI) scan of the dorsal spine with contrast showing the intramedullary contrast-enhancing lesion. 


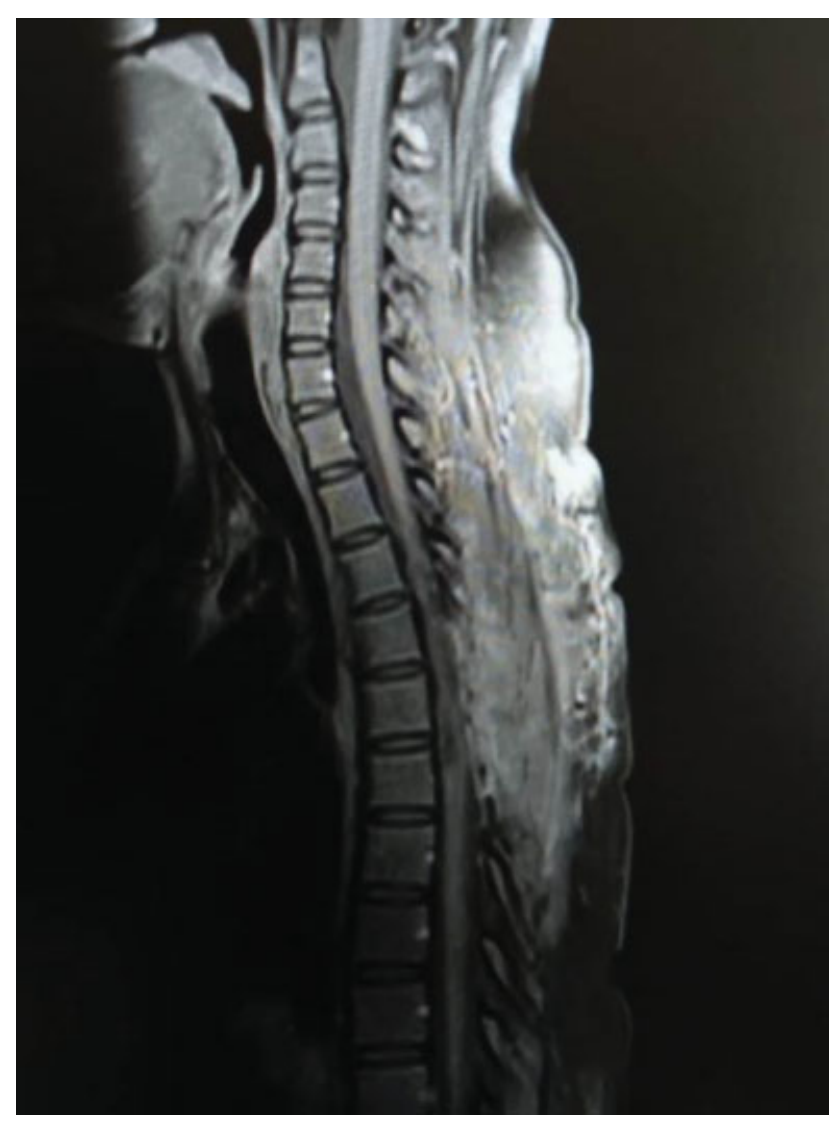

Fig. 4 Intraoperative image showing the lesion within the spinal cord.

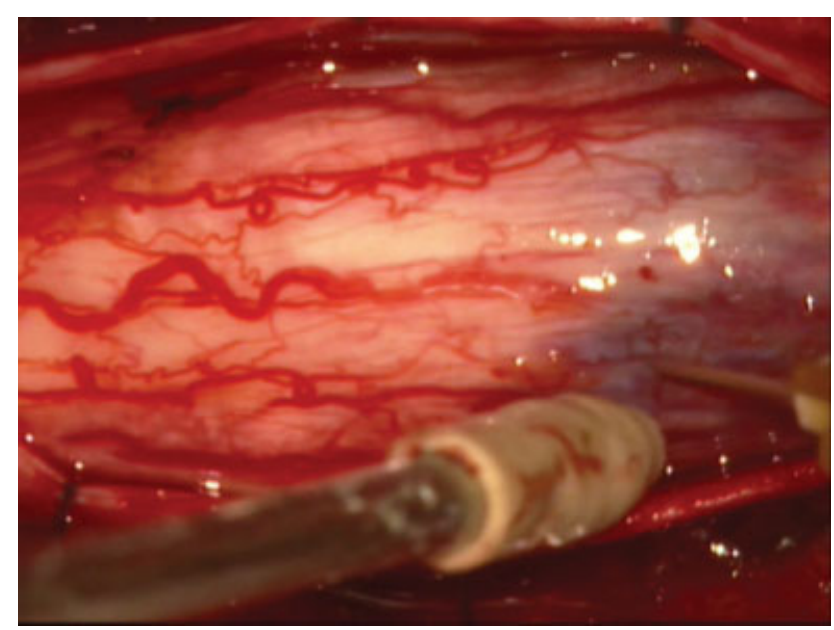

Fig. 5 Intraoperative image showing paramedian myelotomy.

To our surprise, the histopathology was suggestive of spindle-cell tumor with pallisading architecture and intratumoral aggregates of pigments in the hemosiderin-laden macrophages with cystic changes that is, schwanomma (- Fig. 8).

\section{Discussion}

Spinal schwannomas are the most common primary spinal tumors, accounting for $\sim 25 \%$ of primary intradural spinal cord tumors in adults. Males and females are equally affected, and the age of onset is usually between 25 and 50 years.

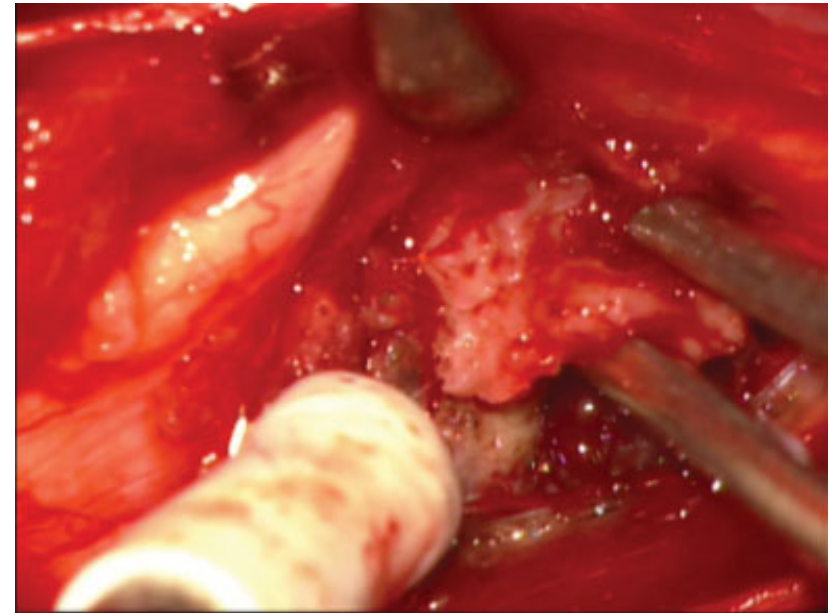

Fig. 6 Intraoperative image showing gradual piecemeal removal of the intramedullary lesion.

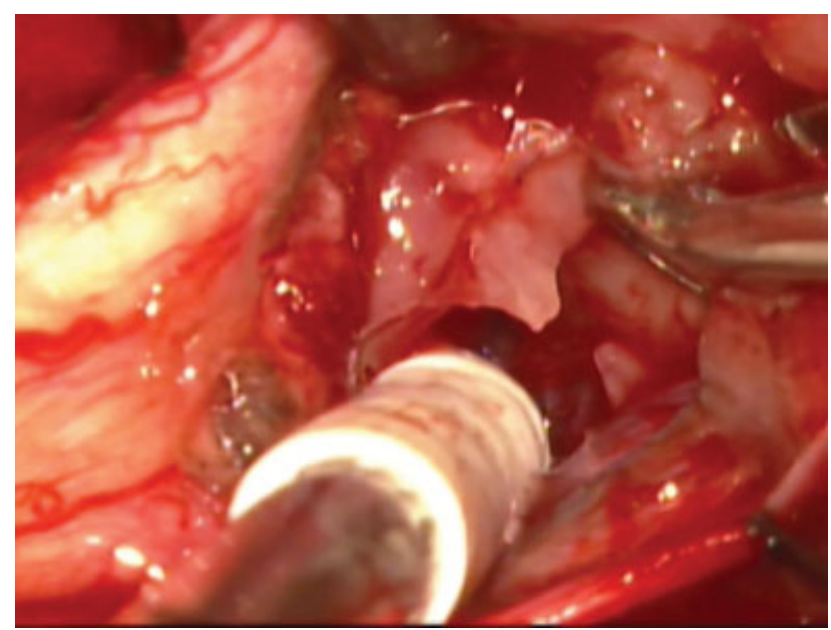

Fig. 7 Intraoperative image after complete removal of the lesion showing the cavity within the cord.

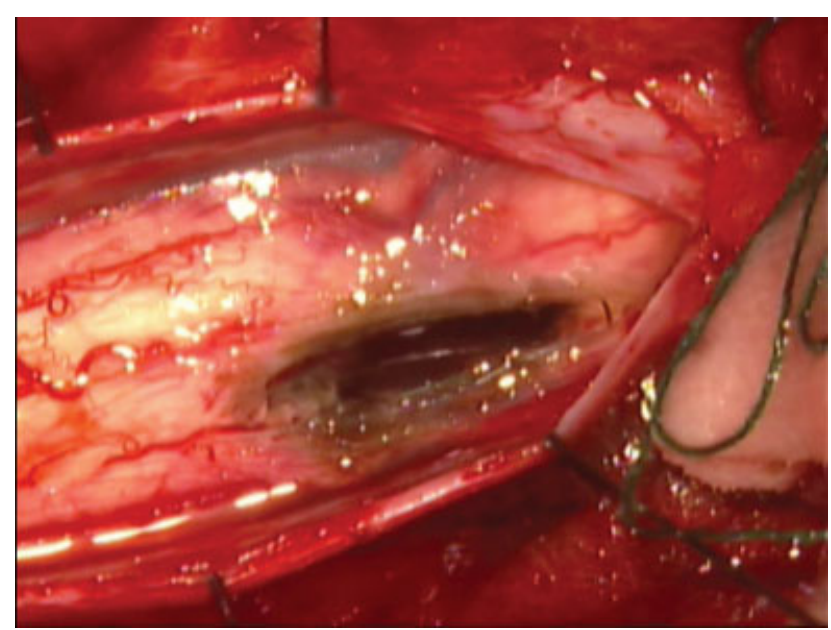

Fig. 8 Postoperative MRI of the dorsal spine showing complete excision of the lesion.

Hirano et al. reported an extended series of 678 spinal cord tumors: schwannomas were the most common histological type, with a slight prevalence of the male sex. The symptoms are related to tumor location and its proximity to the spinal 
cord. Most studies report pain as the first symptom, followed by sensory deficits. Motor deficits and sphincter impairment are observed relatively late. The gold standard for the preoperative diagnosis of spinal schwannoma is the MRI. Schwannomas are more commonly observed in the lumbar spine. In the literature, $70 \%$ to $80 \%$ of spinal schwannomas are reported to be intradural in location, followed by dumbbell tumors, with both intradural and extradural components accounting for another $15 \%$. Surgical resection is considered the gold standard for the treatment of spinal schwannomas. ${ }^{4,5}$

IS was first reported in 1931 by pathologist James Kernohan. However, to date, less than 70 cases of IS have been reported, most of them cervical, with less than 20 in the dorsal region. The most common location of ISs in order of frequency are the cervical spine (63\%), and the thoracic (26\%) and lumbar (11\%) levels. Intramedullary schwanommas are benign but clinically progressive lesions. Early surgical intervention remains the gold standard treatment before the neurological deficits develop. ${ }^{1}$

The intramedullary location is rare, since the origin of the schwanomma is the Schwann cells, which are not normally found within the parenchyma of the brain and spinal cord. This has raised speculations about its pathogenesis, and has led to several theories to explain the origin of these tumors, although none has gained acceptance. ${ }^{1,3}$

The theories regarding the possible genesis that have been postulated $^{3}$ are:

- central displacement of Schwann cells during embryonic development;

- Schwann cells ensheathing aberrant intramedullary nerve fibers;

- Schwann cells extending along the intramedullary perivascular nerve plexus;

- possible neoplastic growth from dorsal-root Schwann cells located in a "critical area," as suggested by Mason and Keigher, in which the posterior roots lose their sheaths upon entering the pia mater; and

- transformation of pial cells of neuroectodermal origin into Schwann cells.

Wood et al. made two important observations: first, that schwannomas are usually located posteriorly/posterolaterally, and second, that the tumoral vascular plexus, if observed during surgery, always originates from anterior spinal arteries, never from posterior spinal arteries. A case of dumbbellshaped neurofibroma with intramedullary and extramedullary components has been reported by Gorman et al., supporting the hypothesis of a "critical area."

The modality of choice for the diagnosis of intraspinal tumors is the MRI. Intramedullary schwannomas usually present with two patterns: solid lesions without a cystic portion; and cystic-solid lesions with associated cyst formation. The solid portion is isointense to hypointense on T1weighted images; T2-weighted images usually show a hyperintense signal, with occasional isointense or low-signal areas. Segmental fusiform dilation of the cord is common, and peritumoral edema, which is usually present in astrocytoma, is uncommon. Contrast-enhanced T1-weighted images better delineate the lesion and differentiate the solid from the cystic components and edema. After gadolinium administration, variable enhancement can be found, and heterogeneous enhancement is the most common, with a few cases showing homogeneous and circular enhancement. The preoperative diagnosis of an IS purely on radiological grounds is difficult, as it is also difficult to differentiate it from intramedullary gliomas. However, in ISs, the classic dumb-bell appearance is rarely observed. ${ }^{3,6}$

Histologically, schwannomas are composed of an AntoniA cell areas comprising compact cells in a reticular framework, and Antoni-B cell areas comprising large cells in a loose collagenous background. Intramedullary schwannomas do not have any specific histological feature. ${ }^{6}$

As most of these lesions are well-demarcated, gross total excision of the lesion with minimal damage to the surrounding neural tissue remains the gold standard treatment. However, subtotal resection can be performed if it is adherent to surrounding neural tissue. The use of advanced neurosurgical techniques, surgical microscope and a cavitron ultrasonic suction aspirator (CUSA) have resulted in better removal of intramedullary tumors by reducing tumor volume, with minimal retraction of the spinal cord, yielding better results. ${ }^{3}$

\section{Conclusion}

Intramedullary schwanommas are histologically benign tumors, and complete functional recovery can be achieved after early total excision. They are difficult to diagnose preoperatively, as there are no pathognomonic signs that enable its differentiation from other intramedullary tumors. Therefore, IS should be considered in the differential diagnosis of an intramedullary lesion in the thoracic spine.

Conflict of Interests

The authors have no conflict of interests to declare.

\section{References}

1 Navarro Fernández JO, Monroy Sosa A, Cacho Díaz B, et al. Cervical Intramedullary Schwannoma: Case Report and Review of the Literature. Case Rep Neurol 2018;10(01):18-24

2 Li X, Xu G, Su R, Lv J, Lai X, Yu X. Intramedullary schwannoma of the upper cervical spinal cord: a case study of identification in pathologic autopsy. Forensic Sci Rev 2017;2(01):46-49. Doi: 10.1080/20961790.2016.1265236

3 Herregodts P, Vloeberghs M, Schmedding E, Goossens A, Stadnik T, D'Haens J. Solitary dorsal intramedullary schwannoma. Case report. J Neurosurg 1991;74(05):816-820

4 Lenzi J, Anichini G, Landi A, et al. Spinal Nerves Schwannomas: Experience on 367 Cases-Historic Overview on How Clinical, Radiological, and Surgical Practices Have Changed over a Course of 60 Years. Neurol Res Int 2017;2017:3568359. Doi: 10.1155/2017/ 3568359

5 Jeon JH, Hwang HS, Jeong JH, Park SH, Moon JG, Kim CH. Spinal schwannoma; analysis of 40 cases. J Korean Neurosurg Soc 2008; 43(03):135-138. Doi: 10.3340/jkns.2008.43.3.135

6 Nicácio JM, Rodrigues JC, Galles MH, Faquini IV, de Brito Pereira CA, Ganau M. Cervical intramedullary schwannoma: a case report and review of the literature. Rare Tumors 2009;1(02):e44. Doi: 10.4081/rt.2009.e44 